\author{
N. V. KRYVTSOVA ${ }^{1^{*}}$, I. A. DONNIKOVA ${ }^{2 *}$ \\ 1* Odessa National Medical University (Odessa, Ukraine), e-mail kryvtsova.natalya@gmail.com, ORCID 0000-0003-1965-6635 \\ ${ }^{2 *}$ National University "Odessa Maritime Academy" (Odessa, Ukraine), e-mail irinadonnikova281@gmail.com, \\ ORCID 0000-0002-8504-1578
}

\title{
ANTHROPOLOGIZATION OF SCIENCE: FROM THE SUBJECT OF COGNITION TO THE RESEARCHER'S PERSONALITY
}

\begin{abstract}
Purpose. With the consideration of anthropological tendencies in modern science, the purpose of the article is to analyze the problem of the subject of cognition, philosophical-psychological rationale for the need to complement it by the concept of "the researcher's personality". Theoretical basis. The authors rely on post-non-classical methodological tools and basic principles of complexity theory (autopoiesis, auto-eco-organization, synergy, syzygy, targeted and cyclic determination), as well as theoretical provisions of epistemological constructivism (enactivism), the results of theoretical and empirical psychological studies. In them, authors revealed psychological features of the potential of self-realization of a person prone to innovation and research activities and transfessionalism, including the resources and reserves of the researcher's personality. Originality. The concept of the subject of (scientific) cognition is expanded by the concept of "researcher's personality" and derivative concepts that describe the dynamics of self-harmonization of originative co-generative strengths and opportunities of self-realization of an enlightened person, reveal the degree of correlation in the cognition of the subjective and objective dimensions of his life. It is substantiated that further analysis of the problem of anthropologization of science requires appropriate ontoepistemological grounds that reveals the unity of cognition-education-skill as an essential characteristic of the maturity of the researcher's personality of scientific knowledge. Conclusions. In the context of anthropological shifts in modern science, the philosophical-psychological analysis of the problem of the subject of cognition is actualized. The psychological research proves the advisability of using the "researcher's personality" concept as a basic one for understanding the formation of an enlightened human-creator, capable of auto-eco-organization, self-transcendence, and syzygy with the Universe at different levels of innovational research activity. The self-realization of the researcher-personality is a way-search for the authenticity of the multiform unity of life, the personal meaning of scientific truth, and the self-harmonization of the originative co-generative co-determinative strengths in the knowledge of an enlightened person. Including the concept of the subject of cognition in the ontology of the unity of differencemultidimensional poly-essential autopoetic integrity, the anthropologization of science is intended to revive the an-

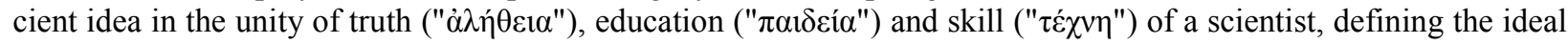
of a modern human-transfessional.

Keywords: anthropologization of science; researcher's personality; subject of (scientific) cognition; multiform unity; enlightened person; paideia; self-realization; originative co-generative co-determinative strengths of knowledge
\end{abstract}

\section{Introduction}

Modern man, immersed in various socio-cultural practices, understands, and even more feels the impossibility of staying away from the movements and transformations of a complex, changing world. However, science endows the individual with the impersonal status of a subject of cognition, which has a dispassionate view of the world-object. So, on the one hand, we have the existential man's dependence on the world that he cognizes; on the other, scientific rationality, which requires distancing from it. Science tries to overcome the subject-object dichotomy by synthesizing theories, methodologies, and paradigms, shifting the disciplinary boundaries, in which one can see the tendencies of anthropologization. At the same time, the issue of the boundaries of anthropologization, the degree in presence of human subjectivity in scientific cognition and knowledge is actualized. 
Against the backdrop of the COVID-19 pandemic, the problem of anthropologization in scientific cognition becomes especially relevant, requiring science to "reconstruct the image of the living", refuse from the subject-object dichotomy, which has transformed into the difference and even hostility of "I" and "Other" (Markov, Sergeev, \& Bocharnikov, 2020, p. 12). Modern culture changes the understanding of the "Other", actualizes the proportionality of humans to the scale of nature and the Universe. It is about the demand for so-called "cultural vitalism", which should connect people with all living things, teach "understanding recognition" (Markov, Sergeev, \& Bocharnikov, 2020, p. 15). We are witnessing global shifts that force us to find the "human" in what until recently was perceived exclusively as "inhuman" - inanimate, unconscious, incorporeal, uncultured, artificial, and so on. In a specific form, "human" manifests oneself and in science by requiring from a person (in a broad sense) literacy, education in relation to the world.

Given the anthropological changes in modern science, there is a need to rethink the subjectobject relationship, in particular, the concept of the subject of cognition. We are talking about identifying the links between cognition and the vivifying practice of humans while maintaining the border between subjectiveness and subjectivity of cognition. Anthropologization of science requires consideration of personal cognitive abilities, innovation-research potential of the person who cognizes, because, according to V. Vernadsky:

Scientific thought does not exist in itself, it is created by a living human personality, it is his manifestation. In the world there are really only individuals who create and express scientific thought ... The scientific thought and scientific discovery created by them ... change the course of the biosphere, nature that surrounds us in the future. (Vernadsky, 1981, p. 233)

In this regard, the importance of philosophical-psychological foundations in the cognitive activity in general and scientific in particular, the analysis for the need to complement the "subject of (scientific) cognition" with the concept of "the researcher's personality" is increasing.

\section{Purpose}

The purpose of the study is to analyze the problem of the subject of cognition in the context of anthropologization of science, the disclosure of the philosophical-psychological aspects in the concept of "researcher's personality" as a basic one in understanding the problem of the subject of cognition.

\section{Statement of basic materials}

Let us clarify once again that in our study we associate the anthropologization of scientific cognition with a rethinking of the concept of the subject of (scientific) cognition and proceed from the fact that science with its desire to identify invariant, universal characteristics and properties of things is one of the ways to unite human with the world. If science divides the world into "subject" and "object", it is only in order to understand it as a whole. 
The first manifestations of the anthropologization of science are associated with the revolution in natural science, in particular with quantum physics, when, according to V. Stepin (2011) "the following types of explanations and descriptions are accepted, which explicitly contain references to means and operations of cognitive activities" (p. 190). It becomes clear that human activity is a mediator between the mind and the world, it determines in what way and by what means of thinking comprehends the world (Stepin, 2011, p. 203). If the ideals and norms of non-classical science implicitly contain the problem of the subject, post-non-classical science directly focuses on the subject, considering him as a bearer of cultural values that are constructed and reproduced in certain social institutions and research communities (Stepin, 2011). The post-non-classical type of scientific rationality reveals a new type of objects: human-dimensional, and also involves the inclusion of axiological factors in the composition of explanatory provisions. As V. Stepin (2011) notes, "when studying human-dimensional systems, the researcher has to solve a number of ethical problems, determining the boundaries of possible interference in the object" (p. 197).

In philosophical and socio-humanitarian knowledge, the anthropological tendency is propagated by the "cultural turn" (K. Jaspers, A. Camus, H. Gadamer, E. Cassirer, etc.), which forces us to focus on life and activity (including cognitive one) as a search for personal meanings. The epistemological attitude "subject precedes to object" arises due to the transcendental phenomenology of E. Husserl, "anthropology of cognition" by P. Feyerabend, as well as "archeology of knowledge" and "discourse" of M. Foucault, who proves that the object of knowledge is constantly created by speech practices.

The current stage of anthropological shifts is largely related to the constructivist paradigm in cognitive science. Developing the ideas of F. Varela and H. Maturana (autopoiesis, which includes the idea of corporeality and situationality), the evolutionary epistemology of K. Lorentz (which emphasizes the identity of life and cognition ("life is cognition")), epistemological constructivism actually destroys the subject-object dichotomy. "Embodied" cognition occurs "hereand-now", acquires its own topology, expands in space-time. It becomes the "realization" in which many meanings are "packed" - the activity of cognition, construction in the process of cognition, co-changing the cognitive agent and the environment (Knyazeva, 2014, p. 90). The enactivist approach focuses on the subject/object interdetermination, approaches the whole, holistic vision of cognition, essentially transforming it into a subject-to-subject relations. Subjectivistic extremes of constructivism, according to its critics, are overcome through a combination with realism, after all, as V. Lektorsky (2018) notes, "a cognitive agent (not necessarily a person) is not a passive receiver of information", it "must take this information through its active actions in the world itself, such actions that include the transformation of the environment" (p. 21).

Cognitive science focuses on the problem of the identity of human cognition (MacLean, 2016), researches its evolutionary roots, structures and mechanisms; it explains how culture, through the human cognitive properties joins him/her to the eco world (Shettleworth, 2012). It should be noted that cognitive science contributes to the actualization of a number of metaphysical issues, creating a new transdisciplinary field. Peter Railton (2019) notes that cognitive science "has a good deal to say about the infrastructure in virtue of which we might, or might not, be moral creatures" (p. 73). Knowledge about the origin, nature, and rationality of moral thought and practice makes it possible to understand how Homo sapiens became the dominant species, despite egocentrism, quarrelsomeness, and even destructiveness (Railton, 2019, p. 93). Therefore, further anthropologization of the problems of cognitive science is expected, which creates conditions for a holistic analysis of both cognition and the person who cognizes. 
In cognitive epistemology special attention should be paid to the active development of the so-called "anthropology beyond/beside humans", as Stefan Helmreich (2014) defines it, and which studies nonhuman objects - "multispecies collectives (including insects, fungi, trees, microbes) as well as, quite recently, water, air, oil, light, mud, and rocks" (p. 267). These objects are certain "hybrid onto-epistemo-forms" including anthropology, the history of mankind (Helmreich, 2014). M. Goodale (2017) also draws the attention of epistemology, "in which humans are reimagined within formations... that have a kind of reality beyond the human". In his view, such epistemology is deeply ecological, important for collective survival, "in which humans occupy profoundly interdependent positions with nonhuman animals, cosmological forces, and the land" (Goodale, 2017, p. 221). The said problematic area expands the meaning in the concept of the subject of cognition, depriving a person of "monopoly" on this status, actualizing the poetically figurative, metaphorical perception of the Universe. Cognition becomes a specific communication all participants of which are active subjects.

Searching for an answer to the question "what is the specificity of the human-subject of cognition?" it is advisable to start with the genesis of the very concept of the subject. Its primary meaning (Latin "subjectus" as the basis) gives reasons to speak about the ontologicalepistemological unity of man with the world, and hence about the indivisibility of the substantial, subjective, and objective. It is worth recalling that the ancient Greeks understood the single sub-

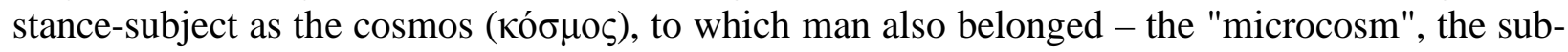
stance-subject that "contemplates" the world, the Logos. That is why knowledge was understood

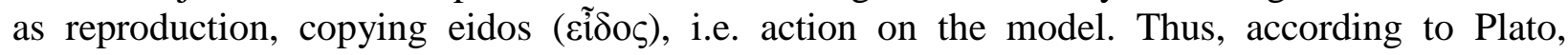
knowledge is a modus of being, a special moment of integration of consciousness. Contrasting the great world with the profane world, the philosopher tried to present different types of knowledge in hierarchical differentiation, retaining their ontological status (Pavlovskiy, 2017,

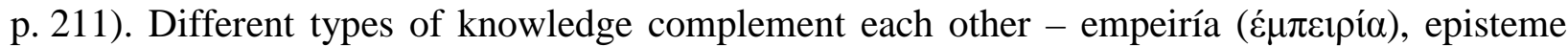

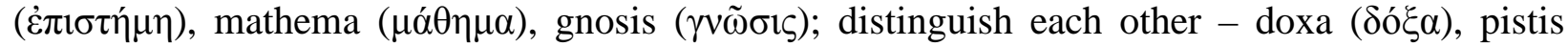

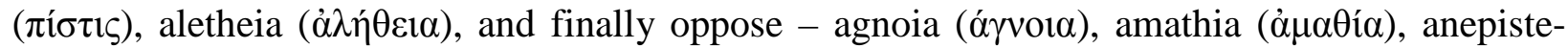
mosyne $(\dot{\alpha} v \varepsilon \pi i \sigma \tau \eta \mu)$. Concepts of "knowledge" and "cognition" in Plato's philosophy become the centers that "draw together" the various spheres of human life, cognitive and beyond cognitive, reproducing the holistic being.

Distinguishing between "gnosis" and "episteme", Plato binds namely the second, "active knowledge", with "techne" ( $\tau \dot{\varepsilon} \chi v \eta)$ - knowledge that has a recipe for how to do something, combines theoretical understanding and practical art. As noted by A. Karpov,

Polysemy of the ancient Greek concept of $\dot{\chi} \chi \vee \eta$ internally carries a pro-

nounced concentrated image that represents the person's way to realizes

oneself in one's destiny; a way that comes from the practices of arts,

crafts and science. The agent of destiny is $\varepsilon \chi \downarrow \eta \imath \tau \eta \varsigma$ is a craftsman, artist,

technician, but at the same time an expert and master. (Karpov, 2016,

p. 118) 
In the hierarchy of knowledge-skills, true skill, which arises on the basis in knowledge of good and evil, is designated by Plato as sophrosyne - general skill, knowledge of knowledges (Losev, 1986, p. 29).

Thus, the unity of human existence and knowledge in Plato means that human is able to use knowledge for self-improvement. According to A. Losev (1986), true knowledge and wise skill are not just health, or physical beauty, nor wealth, agriculture, nor military affairs, nor even tsarist rule (p. 14). A person who is knowledgeable (epistemon) in the work he does is also endowed

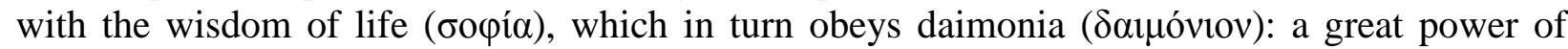
thought, a purely human imperative, unconscious, superpersonal in nature, which spurs the person to do good (Losev, 1986, p. 7). Knowledge-skill gives a happy life, it is associated with wisdom, as well as justice, virtue. Human achieves the fullness of being, the "eidetic truth" through the path of spiritual growth based on self-knowledge and understanding of his unenlightenment. It is in this sense Plato thought about education - "paideia" (Greek " $\pi \alpha 1 \delta \varepsilon i ́ \alpha "$, respectively Latin "Humanitas"), which involves a change of self, the achievement of "arete" through the perfection of "kalokagathia". Thus, an educated person both creates himself and paves the way he goes.

Aristotle also tries to reveal cognition as a path in which human self-improvement occurs. Definition and proof become the main ones on this path. However, as noted by R. Pavlovskiy (2017, p. 213), the theme of knowledge in Aristotle should be considered in the context of psychology, ethics, politics, and metaphysics. Then it becomes clear that knowledge for him is not "an objective content, but a special state of objective completeness of the knower" (Pavlovskiy, 2017, p. 211). If something is missing in the base, there is a gap at the top, so the incompleteness of the subject requires a specific way to close the "breaches", which knowledge is. Aristotle's goal is an active mind and actual knowledge, represented by the highest reality available to man (Pavlovskiy, 2017, p. 214). In this connection, there is reason to take a critical look at the translation of the "episteme" concept ( $\left.\dot{\varepsilon} \pi \_\tau \eta \dot{\mu \eta}\right)$ as "science". The practice of translation gives the meaning of knowledge ( $\dot{\varepsilon} \pi \imath \tau \eta \dot{\mu \eta})$ as a process and event; properties or qualities (Pavlovskiy, 2017, p. 212).

Objective knowledge is researched by Aristotle as a means of effective behavior in a dispute among two subjects who aim to win, to assert their position. But in the future, a sole, monologue concept of knowledge becomes dominant one, in which it is a moment of human existence, related to its goals, moral attitudes, etc. (Pavlovskiy, 2017, p. 214). It was it that initiated the "great breach" (Morin, 2013, p. 36), separating space, "physis”, and human, the ontological and epistemological principles of human existence and transforming human from a "substance-subject" to a subject of cognition. Cognition as a monologue defines the ideals and norms of classical science, the product of which is the epistemological subject. As V. Stepin (2011) notes, the classical type of scientific rationality was limited to "only the first and most general level of reflection over cognitive activity ... Everything that ensures the connection between the subject and the object... did not fall into the field of view of reflexive analysis" (p. 202).

The central role in the transformation of human into a subject of cognition is traditionally assigned to R. Descartes, his subject-object relation acquires the character of extreme contraposition. But, referring to the authoritative opinion of A. Malivskyi (2017, 2020), it can be argued that anthropological issues have not disappeared anywhere either from the philosophical meditations of Descartes, or from the philosophy of the New Age in general. Descartes' philosophy demonstrates a deep interest in human nature, namely, the question "under what conditions human as an imperfect being, can act as a cornerstone of objective knowledge?" (Malivskyi, 2017, p. 121). Descartes' comprehension of the human's holistic nature occurs within the framework of 
"the holistic development of the worldview, beginning with the soulless mathematical nature through the doctrine of inanimate and animate nature to human as the pinnacle of nature and ethics as the theory of its proper behavior" (Malivskyi, 2017, p. 122). The researcher places accents, which determine Descartes rather not as a methodologist-rationalist, but as a metaphysiciananthropologist, for whom it is important to improve human nature through the enrichment of knowledge, and impartial comprehension of truth is a necessary prerequisite for successful selfdevelopment (Malivskyi, 2019, p. 112). Especially, in the study of A. Malivskyi we note the idea that important for us concerning the anthropological search of Descartes. They become clear and viewable through the appeal to the personality of the philosopher and scientist, his path of life, and collisions of self-knowledge.

Thus, it may be affirmed that understanding of the subject-object relationship as a purely epistemological one was formed against the backdrop of anthropological issues and within a certain ontology, creating a special epistemological tension in the philosophy of that time. The most contradictory type of the subject-object relations become in I. Kant (2007). On the one hand, due to the a priori function of the mind, the subject "produces" the object, on the other hand, the relationship between the subject and the object remains directly opposite, in the need of an abstract construct of the transcendental subject. In Kant's (2007) statement that "experience is the construction, organizing the material of sensuality (sensations) by the subject using a priori forms of carnal contemplation and a priori categories of mind" (p. 151), one can recognize the ideas of modern constructivism. But by dividing the transcendental and empirical subjects, Kant deprives the integrity both of the man who cognizes and the object, which becomes phenomenally noumenal.

The further transformation of the subject of cognition turned out to be intrinsically antinomic. As noted by E. Kalinin (2017), on the one hand, the need for a border between the observer and what he observes (i.e. between the subject and the object) is recognized and simultaneously there is the impossibility to remove the observer. In addition, quantum mechanics has revealed contradictions between the empirical individual and the theorist (observer) as well as the individual who cognizes reality and reflects on it (Kalinin, 2017). Therefore, according to the researcher, the analysis of the subject of scientific cognition is possible provided that he identifies own boundaries (subjects of observation, measurement, experimentation, theorizing, etc.), which are united by a single common characteristic - meaning (Kalinin, 2017). In general, supporting the line of the researcher's thinking, we add that the subject himself of (scientific) cognition also arises due to the laying of boundaries - in the individual as a difference-multidimensional polyessential autopoietic integrity (Kryvtsova, 2019), which is the embodiment of subjects in various vital activity including innovation and research works of the scientist. Philosophicalpsychological reflection is able to single out and reveal these subjects as different guises of the holistic person (focusing on the subject of cognition). It is important to realize that the subject of cognition is only a construct that requires a person to change in modifying conditions, and, if necessary, to disengage from reality, to build a subject-object relationship with it, as required by certain types and forms of activity. The subject of cognition discovers the essential features of this activity through the actualization of the research instinct of the individual for adaptation and socialization or socio-psychological self-improvement through the conscious productive selfrealization of innovation and research potential.

In the course of our psychological research, it was empirically confirmed that each stage/level/phase/form in becoming the subject of cognition is accompanied by stage and/or functional transformations of the researcher's personality at the various levels of interaction with 
the Universe (natural, social, cultural and in the organization of life in general) (Kryvtsova, 2018, 2019). In particular, it was possible to substantiate that stability of the interests of the subject of cognition is determined by the degree of connection between the researcher's personality and the Universe, with the main content of one's interests and the presence of a conscious general lifeline in general. Consequently, the formation of the subject of cognition is accompanied by the rising maturity of the researcher's personality and subjective self-determination of an educated person, self-actualization and self-harmonization of originative co-generative codeterminative strengths, and personal/professional self-improvement (Kryvtsova, 2019).

Especially we focus on the obtained results allowing us to emphasize the unity of ontological and epistemological aspects in the research of the potential for self-realization of the researcher's personality. To cognize the world as it is, means, first of all, the realization that individual existence is commensurate with the scale of the Universe, although human recognizes both the world and himself at different scales and levels of correlation with it. Therefore, cognition requires a person to accept and live their own unity with the Universe, in which the educated person and the creative power of one's knowledge and self-realization are born (Donnikova et al., 2020). It is this idea that, in our opinion, lies in the ancient unity of cognition-education-skill (epistemepaideia-techne), which originated in the cosmo- and logos-centric ontology and needs a corresponding rethinking in the context of the anthropologization of science.

If we are talking about a holistic person who in the search for truth learns to apply own mind and faith, rational and irrational, scientific and cultural-valuable, the need for ontology is revealed within which terminological fixation of interdisciplinary transition from the subject of cognition to the holistic subject of vital activity is possible. This issue requires particular research, so we only note that we mean the development of an ontology of the multiform unity of epy enlightened person with the Universe as a subject of psychological philosophy (Donnikova et al., 2020). In this regard, we emphasize once again the special significance for modern anthropological shifts of the ancient "paideia" as an expression of the unity of knowledge and skill to keep the unity of humans with the world.

Since the subject of modern science comprises both research proper and qualities common to humanity, the emphasis shifts to the individual who explores the world as a space-time continuum where both informational and energetic connections with the world at different levels of co-creation and co-revolution are important. Therefore, it is advisable to use the concept of "researcher's personality" and relevant derivative concepts: the researcher's personality of scientific information, scientific knowledge, and information resources, as well as "personality-transfessional" (Kryvtsova, 2018, 2019), which reveal a continuous process of selfactualization and self-harmonization of originative co-generative co-determinative strengths and self-realization of an enlightened person in innovative research activities. Please note that the researcher's personality we consider as a concept-"mediator" between science and human life, subjectival, subjective and objective revealing the dynamics of auto-eco-organization of the subject of cognition and requires an appropriate philosophical-psychological foundation.

The researcher plunges into cognitive activity with the whole "set" of opportunities for selfrealization, including certain knowledge, skills, personal qualities, abilities, resources, and reserves, etc., so he is always the subject of his own life and, at the same time, the object of selfreflection, self-actualization, and self-harmonization of originative co-generative codeterminative strengths. Over time, undifferentiated subject-object relations, accompanied by the emotional attractiveness of "something interesting", the undefined dynamic trend of externally 
determined search activity (common to the researcher's personality, including scientific information) through self-reflection, self-actualization, and self-harmonization of the originative cogenerative co-determinative strengths of knowledge can be transformed into a conscious motive of life-creation researcher's personality of information resources. He is distinguished by the ability to socially significant, conscious, productive cognitive activity in a multiform unity with the Universe (Kryvtsova, 2019).

Therefore, the concept of "the researcher's personality" does not replace the concept of "the subject of cognition", but "absorbs" it, enriches and concretizes. In particular, both the research instinct and the person's ability for conscious productive search activity are expressed in the concept "the researcher's personality of information resources". We mean that the basis for "birth" of the subject of cognition of a higher level is fixed. This subject is capable of selfactualization and self-harmonization of originative co-generative co-determinative strengths and ready for creative self-change in a dynamic environment while maintaining the productivity and authenticity of the own vital activity. In this sense, each person is a subject for whom cognition is an integral part of life, a way of engaging to the whole world, adapting to it or conquering it to oneself.

Ontologically, the subject of cognition belongs to natural and cultural existence, so his ability to cognition should become an ideal example in the ecological unity of the personality-researcher of information resources with the Universe. At the same time, this unity is a boundary that has natural and artificial dimensions of energy-information space-time in human life, and under certain conditions becomes a target and/or cyclical determinant of transformations in the sociopsychological continuum of self-harmonization of originative co-generative co-determinative strengths and self-realization of "personality-transfessional" (Kryvtsova, 2018, 2019). Thus, the concept of "the personality-researcher of information resources" characterizes a person who cognizes as a knowledgeable one: a mature subject who creates the conditions for their own life. Closest to this type/level of researcher's personality is the subject of cognition of post-nonclassical science: knowledge itself becomes a source of resources of auto-eco-causalorganization in all forms of own activity, personal-professional self-improvement, and selfharmonization at different levels of innovation-research interaction and co-creation.

The concept of "researcher's personality of scientific information" reflects the specifics of self-realization of personal potential in scientific cognition. This type of the researcher is characterized by an active but spontaneous and rather superficial scientific-information search. For them, scientific professional activity does not have yet a particular impact on the meaning of their own life. Scientific facts remain external to its existential meanings and the knowledge gained is deprived of the prospect of transforming into the personal life values, so the cognizable world in response becomes an "indifferent" object.

To characterize the conscious purposeful cognitive activity, which is associated with the possibility of subjective self-determination and self-actualization of the originative co-generative codeterminative strengths of an enlightened person, it is advisable to use the concept of "the researcher's personality of scientific knowledge". In this case, it is about a professional research activity that requires a person to have certain cognitive tools, to be a part of the scientific community, to share its ideals and norms. Exactly with scientific activity, the possibility of "awakening" in the personal potential of the subject of cognition as an enlightened person is connected for transformation into a mature researcher's personality of the information resources. He acts both as a subject of cognition and as an inventor of meaning-forming units of truth - originative 
co-generative co-determinative strengths in the creative knowledge of the enlightened man. However, due to the dominance of cumulative processes of self-reflection, the subject-object dichotomy in the "human-science" system network remains.

The natural striving of a human to cognize gradually becomes a conscious motive of his life, and the process of cognition itself presupposes the simultaneous distribution and interaction of difference-multidimensional trends, the result of which is presented in a state of dynamic rest the prerequisite and background of further activity. The original subject-object dichotomy of cognition/self-knowledge gives way to a holistic system-network in meanings-senses-values of "external" and/or "internal" dimensions of innovative-research activities, co-creation, and coevolution with the Universe at different levels: natural, social, cultural, and in the organization of their own lives in general. At the same time, the likelihood of normative heuristic self-realization of the personality-transfessional as a more or less conscious self-transcendence, auto-ecoorganization, and synergy at different levels increases, but it requires the unity of empirical and transcendent experience while retaining their own uniqueness and authenticity of life. At this stage of cognition, epistemological and ontological boundaries between subject and object disappear, their relativity, transparency, mobility are revealed (Kalmykova, Kharchenko, Volzhentseva, Kalmykov, \& Mysan, 2020). The new difference-multidimensional poly-essential autopoietic integrity arises, which directs the originative co-generative co-determinative strengths of knowledge of a well-informed person and chooses the scale of energy-information space-time of organized disorganization in life and self-transcendence of the personalityresearcher (the hyphen indicates the presence of synergistic effects of multiform unity with the Universe) (Kryvtsova, 2018, 2019).

Seeing the individual in the subject of cognition, we emphasize once again that he is formed in the socio-historical information-communicative space-time of cultural life and professional activity and in this sense is always "a product of its era". Simultaneously, developing the subject of cognition (as a "self-made-man") is always an individual process, being in which the educated person learns to trust himself, his own intellectual intuition, thoughts, ideas, and suchlike. The subject of scientific cognition is also in dynamics and transformations. This is the path from the uncritical perception of "truth" by the researcher's personality (knowledge in the ancient sense as "pistis-doxa"), reproductive-adaptive activity of the researcher's personality of scientific information (knowledge as "empeiría"), creative self-realization of the researcher's personality of scientific knowledge (knowledge as "episteme") toward self-actualization and selfharmonization of originative co-generative co-determinative strengths (knowledge as

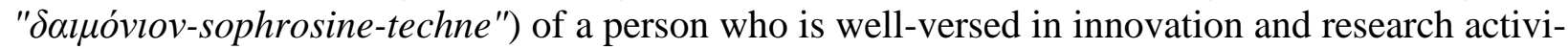
ties in the multiform unity of the personality-researcher of information resources with the Universe and ready for self-realization of the personality-transfessional (Kryvtsova, 2018, 2019). Therefore, this is primarily a matter of determining their own ontological status as an enlightened person by the subject of cognition.

The three-pronged search process - personal truths (the meaning of one's own life), scientific truth, originative co-generative co-determinative strengths of knowledge through education and awareness - distinguishes the transfessional from researchers of scientific information and scientific knowledge, reveals the transformation of the subject of cognition into a well-informed mancreator capable of subjective self-determination, auto-eco-organization, self-transcendence and syzygy with the Universe. If we use ancient terms, the key in this process is the interaction of "aletheia" (truth), "paideia" (education), and "techne" (skill). 
Cognition as a real process is the advancement of the researcher's personality from unawareness to the creative knowledge of the enlightened person, changing the focus of world perception and viewpoint on usual things, as well as refusing to understand and perceive everything that exists through an outdated but familiar stencil of knowledge. In the process of selfdetermination of a person who cognizes the world and a person open up to each other as difference-multidimensional, poly-essential autopoietic integrities, ready for co-creation, act as subjects-substances exchanging entities, forming a multiform unity.

We emphasize the importance of education-paideia in the formation of the personalitytransfessional. After all, education is associated not only with changes in the perception of everything that exists as processes-transitions from one stage of cognition to another but also with the moment of adaptation to something new, open to oneself. Moreover, it is precisely the moment of adaptation, "here and now" is the "paideia" in all its power to transform the human soul, a holistic state of understanding (mind-skill). In the "turning eyes" of the researcher's personality to the sense-forming units of truth - "knowledge of knowledges" (ancient "sofrosyne"), that is the essence of education. In view of this, it should be noted that the anthropologization of science also presumes the anthropologization of education.

Thus, the stages of self-determination and self-realization of the researcher's personality, selfactualization, and self-harmonization of originative co-generative co-determinative strengths, reflect the penetration depth of the human subject of cognition into the essence of things and into the own, individual-human essence. Summarizing, one can state: if the initial "cognitive position" of the subject of cognition is a distancing from the world, the essence of which he tries to comprehend, the researcher's personality comes from existential unity with the world, trying to understand it in the process of cognition, self-determination, and self-realization of a knowledgeable person. Thus, the real world is cognized through real transformations of the individual.

We believe that the further development of the "researcher's personality" concept will contribute to rethinking the concept of the subject of (scientific) cognition, directing science and scientists to the ideal of an enlightened person-transfessional.

\section{Originality}

The problem of the subject of (scientific) cognition is considered in the context of anthropologization of science. It is proposed to complete the concept of "the subject of cognition" with the concept of "the researcher's personality" and derivative concepts "the researcher's personality of scientific information", "the researcher's personality of scientific knowledge". The depth of transformations of the subject of cognition is revealed through the concepts of "the researcher's personality", "the researcher's personality of information resources" and "personality-transfessional". It is substantiated that further analysis of the problem in anthropologization of science requires appropriate onto-epistemological principles, which represent the unity of cognition-education-skill ( $\dot{\varepsilon} \pi 1 \sigma \tau \eta \dot{\mu} \mu \eta-\pi \alpha 1 \delta \varepsilon i ́ \alpha-\tau \dot{\varepsilon} \chi \vee \eta)$.

\section{Conclusions}

Against the backdrop of anthropological changes in modern science, the philosophicalpsychological analysis of the problem of the subject (scientific) cognition is actualized. It is expedient to use the concept of "the researcher's personality" as a basis for revealing the transformations of the subject of cognition into the enlightened human-creator, capable of self- 
determination, auto-eco-organization, self-transcendence, and syzygy. It is a journey from the uncritical perception of truth by the researcher's personality, reproductive-adaptive activity of the researcher's personality of scientific information, creative self-realization of the researcher's personality of the scientific knowledge to the self-realization of the researcher's personality of information resources, who well-informed in innovational research activity and ready for transfessionalism. For the personality-transfessional, cognition becomes a threefold process of searching for the authenticity of one's own life, the personal meaning of scientific truth, and the selfharmonization of the originative co-generative co-determinative strengths of the differencemultidimensional poly-essential autopoietic integrity of the subject of life. Given the above, the anthropologization of science is intended to revive the ancient idea of the unity of truth

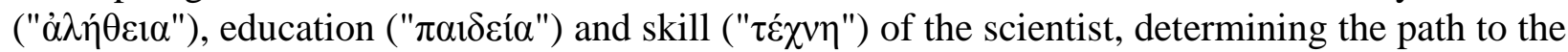
multiform unity of the contemporary personality-researcher-transfessional with the Universe.

\section{REFERENCES}

Donnikova, I. A., Kryvtsova, N. V., Shevchuk, O. M., Kasperovych, H. I., Pavlova, O. S., Ivanova, Y. M. ... Maiboroda, P. A. (2020). Stvoriuvalna syla znannia: Monohrafiia: Knyha persha. Odessa: Feniks. (in Ukrainian)

Goodale, M. (2017). Anthropology and Law: A Critical Introduction. NYU Press. DOI: https://doi.org/10.2307/ j.ctt1ggjjgh (in English)

Helmreich, S. (2014). Waves: An anthropology of scientific things. HAU: Journal of Ethnographic Theory, 4(3), 265-284. DOI: http://doi.org/10.14318/hau4.3.016 (in English)

Kalinin, E. U. (2017). The problem of subject in modern physics and cosmology. Vox, 22, 105-116. DOI: http://doi.org/10.24411/2077-6608-2017-00011 (in Russian)

Kalmykova, L., Kharchenko, N., Volzhentseva, I., Kalmykov, H., \& Mysan, I. (2020). Actualization of the Internal Speech Problems in Psycholinguistics of Communication: The Results of a Systematic Review and MetaAnalysis. Psycholinguistics, 28(1), 83-148. DOI: https://doi.org/10.31470/2309-1797-2020-28-1-83-148 (in Ukrainian)

Kant, I. (2007). Kritika chistogo razuma. N. Losskiy, Trans. from German. Moscow: Eksmo. (in Russian)

Karpov, A. O. (2016). Antique Ontology in Education for the Knowledge Society. Philosophy of education, 1(64), 113-129. DOI: http://doi.org/10.15372/PHE20160112 (in Russian)

Knyazeva, Y. N. (2014). Enaktivizm: Novaya forma konstruktivizma v epistemologii. Moscow: Tsentr gumanitarnykh initsiativ. (in Russian)

Kryvtsova, N. V. (2018). Psykholohichni osoblyvosti potentsialu samorealizatsii osobystosti. (Dysertatsiia kandydata psykholohichnykh nauk). Odessa I. I. Mechnikov National University, Odessa. (in Ukrainian)

Kryvtsova, N. V. (2019). Shliakh do harmonii zhyttia: Teoriia i praktyka samorealizatsii: Monohrafiia. Kharkiv: Fakt. (in Ukrainian)

Lektorsky, V. A. (2018). Constructive realism as the contemporary form of epistemological realism. Philosophy of Science and Technology, 23(2), 18-22. DOI: http://doi.org/10.21146/2413-9084-2018-23-2-18-22 (in Russian)

Losev, A. F. (1986). Rannie dialogi Platona i sochineniya platonovskoy shkoly. In Plato, Dialogi (pp. 3-65). Moscow: Mysl. (in Russian)

MacLean, E. L. (2016). Unraveling the evolution of uniquely human cognition. Proceedings of the National Academy of Sciences, 113(23), 6348-6354. DOI: https://doi.org/10.1073/pnas.1521270113 (in English)

Malivskyi, A. M. (2017). Anthropological Project as a Basis of Cartesian Ethics. Anthropological Measurements of Philosophical Research, 11, 117-126 DOI: https://doi.org/10.15802/ampr.v0i11.105495 (in Ukrainian)

Malivskyi, A. M. (2019). Neznanyi Dekart: Antropolohichnyi vymir u filosofuvanni: Monohrafiia. Dnipro: Herda. (in Ukrainian)

Markov, B. V., Sergeev, A. M., \& Bocharnikov, V. N. (2020). The Pandemic Phenomenon Through the Prism of Its Metaphysical, Anthropological, and Social Dimensions. Chelovek, 31(3), 7-24. DOI: http://doi.org/ 10.31857/S023620070010034-4 (in Russian) 
Morin, E. (2013). La Méthode. La Nature de la Nature (2nd ed.). Y. N. Knyazeva, Trans from French. Moscow: "Kanon+" ROOY "Reabylytatsyia". (in Russian)

Pavlovskiy, R. V. (2017). On the question of Aristotle's relation to Plato: A problem of knowledge. Vestnik of St. Petersburg University. Philosophy and Conflict Studies, 33(2), 207-216. DOI: https://doi.org/10.21638/ 11701/spbu17.2017.208 (in Russian)

Railton, P. (2019). Moral Metaphysics, Moral Psychology, and the Cognitive Sciences. In A. I. Goldman \& B. P. McLaughlin (Eds.), Metaphysics and Cognitive Science (pp. 73-98). Oxford University Press. DOI: https://doi.org/10.1093/oso/9780190639679.003.0004 (in English)

Shettleworth, S. J. (2012). Modularity, comparative cognition and human uniqueness. Philosophical Transactions of the Royal Society B: Biological Sciences, 367(1603), 2794-2802. DOI: https://doi.org/10.1098/ rstb.2012.0211 (in English)

Stepin, V. S. (2011). Tsivilizatsiya i kultura. St. Petersburg: SPbGUP. (in Russian)

Vernadsky, V. I. (1981). Izbrannye trudy po istorii nauki. Moscow: Nauka. (in Russian)

\section{LIST OF REFERENCE LINKS}

Доннікова I. А., Кривцова Н. В., Шевчук О. М., Касперович Г. І., Павлова О. С., Іванова С. М., Натаров В. П., Ковбан А. В., Майборода П. А. Створювальна сила знання : монографія. Книга перша. Одеса : Фенікс, 2020. 250 с.

Goodale M. Anthropology and Law: A Critical Introduction. NYU Press, 2017. 320 p. DOI: https://doi.org/10.2307/ j.ctt1ggjjgh

Helmreich S. Waves: An anthropology of scientific things. HAU: Journal of Ethnographic Theory. 2014. Vol. 4. No. 3. P. 265-284. DOI: https://doi.org/10.14318/hau4.3.016

Калинин Э. Ю. Проблема субъекта в современной физике и космологии. Vох. Философский журнал. 2017. Вып. 22. С. 105-116. DOI: http://doi.org/10.24411/2077-6608-2017-00011

Kalmykova, L., Kharchenko, N., Volzhentseva, I., Kalmykov, H., Mysan, I. Actualization of the Internal Speech Problems in Psycholinguistics of Communication: The Results of a Systematic Review and Meta-Analysis. Psycholinguistics. 2020. Vol. 28. No. 1. P. 83-148. DOI: https://doi.org/10.31470/2309-1797-2020-28-183-148

Кант И. Критика чистого разума / пер. с нем. Н. Лосского. Москва : Эксмо, 2007. 399 с.

Карпов А. О. Античная онтология в образовании для общества знаний. Философия образования. 2016. № 1 (64). C. 113-129. DOI: http://doi.org/10.15372/PHE20160112

Князева Е. Н. Энактивизм: новая форма конструктивизма в эпистемологии. Москва : Центр гуманитарных инициатив, 2014. $352 \mathrm{c.}$

Кривцова Н. В. Психологічні особливості потенціалу самореалізації особистості : дис. ... канд. психол. наук. Одес. нац. ун-т ім. І. І. Мечникова. Одеса, 2018. 289 с.

Кривцова Н. В. Шлях до гармонї життя: теорія і практика самореалізащії : монографія. Харків : Факт, 2019. $404 \mathrm{c}$.

Лекторский В. А. Конструктивный реализм как современная форма эпистемологического реализма. Философия науки и техники. 2018. Т. 23. № 2. C. 18-22. DOI: http://doi.org/10.21146/2413-9084-2018-23-218-22

Лосев А. Ф. Ранние диалоги Платона и сочинения платоновской школы. Диалоги / Платон. Москва : Мысль, 1986. C. 3-65.

MacLean E. L. Unraveling the evolution of uniquely human cognition. Proceedings of the National Academy of Sciences. 2016. Vol. 113. Iss. 23. P. 6348-6354. DOI: https://doi.org/10.1073/pnas.1521270113

Малівський А. М. Антропологічний проект як підгрунтя картезіанської етики. Антропологічні виміри філософських досліджень. 2017. № 11. С. 117-126. DOI: https://doi.org/10.15802/ampr.v0i11.105495

Малівський А. М. Незнаний Декарт: антропологічний вимір у філософуванні : монографія. Дніпро : Герда, 2019. 300 c.

Марков Б. В., Сергеев А. М., Бочарников В. Н. Феномен пандемии сквозь призму метафизического, антропологического и социального измерений. Человек. 2020. Т. 31. № 3. C. 7-24. DOI: http://doi.org/ 10.31857/S023620070010034-4

Морен Э. Метод. Природа Природы / пер. с фр. Е. Н. Князевой. 2-е изд., доп. Москва : "Канон+" РООИ "Реабилитация", 2013. 464 с. 
Павловский Р. В. К вопросу об отношении Аристотеля к Платону: проблема знания. Вестник СПбГУ. Философия и конфликтология. 2017. Т. 33. Вып. 2. С. 207-216. DOI: https://doi.org/10.21638/11701/ spbu17.2017.208

Railton P. Moral Metaphysics, Moral Psychology, and the Cognitive Sciences. Metaphysics and Cognitive Science / eds. by. A. I. Goldman, B. P. McLaughlin. Oxford University Press, 2019. P. 73-98. DOI: https://doi.org/ 10.1093/oso/9780190639679.003.0004

Shettleworth S. J. Modularity, comparative cognition and human uniqueness. Philosophical Transactions of the Royal Society B: Biological Sciences. 2012. Vol. 367. Iss. 1603. P. 2794-2802. DOI: https://doi.org/ 10.1098/rstb.2012.0211

Степин В. С. Цивилизащия и культура. Санкт-Петербург : СПбГУП, 2011. 408 с.

Вернадский В. И. Избранные труды по истории науки. Москва : Наука, 1981.360 с.

\section{Н. В. КРИВЦОВА ${ }^{1 *}$, І. А. ДОННІКОВА ${ }^{2 *}$}

1* Одеський національний медичний університет (Одеса, Україна), ел. пошта kryvtsova.natalya@gmail.com, ORCID 0000-0003-1965-6635

${ }^{2 *}$ Національний університет "Одеська морська академія" (Одеса, Україна), ел. пошта irinadonnikova281@gmail.com, ORCID 0000-0002-8504-1578

\section{АНТРОПОЛОГІЗАЦІЯ НАУКИ: ВІД СУБ'СКТА ПІЗНАННЯ ДО ОСОБИСТОСТІ ДОСЛІДНИКА}

Мета. 3 урахуванням антропологічних тенденцій у сучасній науці мета статті полягає в аналізі проблеми суб'єкта пізнання, філософсько-психологічному обгрунтуванні необхідності доповнення його концептом "особистість дослідника". Теоретичний базис. Автори спираються на постнекласичний методологічний інструментарій та основні принципи теорії складності (автопоезиса, авто-еко-організації, синергії, сизигії, цільової і циклічної детермінації), а також теоретичні положення епістемологічного конструктивізму (енактивізм), результати теоретичних і емпіричних психологічних досліджень, в яких виявлено психологічні особливості потенціалу самореалізації особистості, схильної до інноваційно-дослідницької діяльності і трансфесіоналізму, в тому числі, ресурси і резерви особистості дослідника. Наукова новизна. Поняття суб'єкта (наукового) пізнання розширено концептом "особистість дослідника" і похідними концептами, які описують динаміку самогармонізації створювальних сил і можливості самоздійснення обізнаної людини, розкривають міру співвідношення в пізнанні суб'єктивного і об'єктивного вимірів ії життєдіяльності. Обгрунтовано, що подальший аналіз проблеми антропологізації науки потребує відповідних онто-епістемологічних підстав, що розкривають єдність пізнанняосвіченості-майстерності як сутнісну характеристику зрілості особистості дослідника наукових знань. Висновки. У контексті антропологічних зрушень у сучасній науці актуалізується філософсько-психологічний аналіз проблеми суб'єкта пізнання. Психологічні дослідження доводять доцільність використання концепту "особистість дослідника" як базового для розуміння становлення освіченої людини-творця, здатної до авто-екоорганізації, самотрансенденції і сизигії з Всесвітом на різних рівнях інноваційно-дослідницької діяльності. Самоздійснення особистості-дослідника - це шлях-пошук автентичності мультиформної єдності життя, особистого сенсу наукової істини і самогармонізації створювальних сил знання обізнаної людини. Включаючи поняття суб'єкта пізнання в онтологію єдності різницево-багатовимірної полісутнісної автопоетичної цілісності, антро-

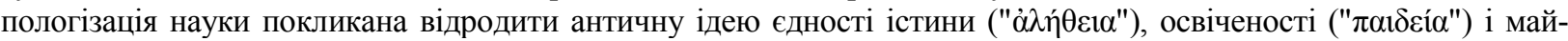

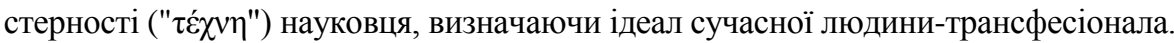

Ключові слова: антропологізація науки; особистість дослідника; суб’єкт (наукового) пізнання; мультиформна єдність; освічена людина; пайдейя; самоздійснення особистості-дослідника; створювальні сили знання

\section{Н. В. КРИВЦОВА ${ }^{1 *}$, И. А. ДОННИКОВА ${ }^{2 *}$}

\footnotetext{
${ }^{1 *}$ Одесский национальный медицинский университет (Одесса, Украина), эл. почта kryvtsova.natalya@gmail.com, ORCID 0000-0003-1965-6635

${ }^{2 *}$ Национальный университет "Одесская морская академия" (Одесса, Украина), эл. почта irinadonnikova281@gmail.com, ORCID 0000-0002-8504-1578
} 


\section{АНТРОПОЛОГИЗАЦИЯ НАУКИ: ОТ СУБЪЕКТА ПОЗНАНИЯ К ЛИЧНОСТИ ИССЛЕДОВАТЕЛЯ}

Цель. С учетом антропологических тенденций в современной науке цель статьи заключается в анализе проблемы субъекта познания, философско-психологическом обосновании необходимости дополнения его концептом "личность исследователя". Теоретический базис. Авторы опираются на постнеклассический методологический инструментарий и основные принципы теории сложности (автопоезиса, авто-экоорганизации, синергии, сизигии, целевой и циклической детерминации), а также на теоретические положения эпистемологического конструктивизма (енактивизм), результаты теоретических и эмпирических психологических исследований, в которых обнаружены психологические особенности потенциала самореализации личности, склонной к инновационно-исследовательской деятельности и трансфессионализму, в том числе, ресурсы и резервы личности исследователя. Научная новизна. Понятие субъекта (научного) познания расширено концептом "личность исследователя" и производными концептами, которые описывают динамику самогармонизации созидательных сил и возможности самореализации знающего человека, раскрывают меру соотношения в познании субъективного и объективного измерений его жизнедеятельности. Обосновано, что дальнейший анализ проблемы антропологизации науки требует соответствующих онтоэпистемологических оснований, раскрывающих единство познания-образованности-мастерства как сущностную характеристику зрелости личности исследователя научных знаний. Выводы. В контексте антропологических сдвигов в современной науке актуализируется философско-психологический анализ проблемы субъекта познания. Психологические исследования доказывают целесообразность использования концепта "личность исследователя" как базового для понимания становления образованного человека-творца, способного к авто-эко-организации, самотрансценденции и сизигии с Вселенной на разных уровнях инновационноисследовательской деятельности. Самореализация личности-исследователя - это путь-поиск автентичности мультиформного единства жизни, личного смысла научной истины и самогармонизации созидательных сил знания образованного человека. Включая понятие субъекта познания в онтологию единства разностномногомерной полисущностной автопоетичной целостности, антропологизация науки призвана возродить

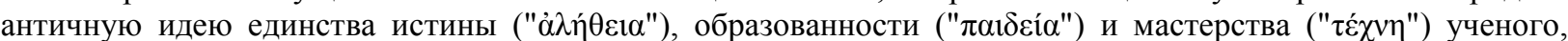
определяя идеал современной человека-трансфесионала.

Ключевые слова: антропологизация науки; личность исследователя; субъект (научного) познания; мультиформное единство; образованный человек; пайдейя; самореализации личности-исследователя; созидательные силы знания

Received: 26.06.2020

Accepted: 17.11.2020 